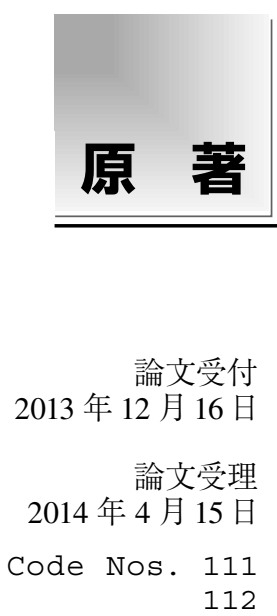

\section{体表指標を用いた肩関節 True Anterior-Posterior 撮影の検討}

\author{
森田峻輔 ${ }^{1}$ 藤澤宏信 ${ }^{2}$ 加藤京一 ${ }^{2,3}$ 西中直也 ${ }^{4}$ 筒井廣明 ${ }^{4,5}$ 中澤靖夫 ${ }^{3,6}$ \\ ${ }^{1}$ 昭和大学藤が丘リハビリテーション病院放射線室 \\ 2 昭和大学藤が丘病院放射線室 \\ 3 昭和大学大学院保健医療学研究科 \\ ${ }^{4}$ 昭和大学藤が丘病院整形外科 \\ 5 昭和大学藤が丘リハビリテーション病院スポーツ整形外科 \\ 6 昭和大学統括放射線技術部
}

\section{緒 言}

肩関節正面像の撮影には，X線束を体幹の前額面に 対して直交するように矢状方向から撮影する routine anterior-posterior 撮影 (routine AP 撮影) と肩甲上腕関節と 肩峰下面の裂隙を描出する方向に撮影する true anteriorposterior 撮影 (true AP 撮影)がある ${ }^{1}$ ）前者は，肩鎖関
節が明瞭に描出されるため, 肩鎖関節の狭小化や亜脱 臼などを見つけやすく，外傷などのスクリーニング撮影 として有用である。一方後者は, 関節裂隙が明瞭に描 出されるため, 肩甲上腕関節の変形性関節症に伴う裂 隙の狭小化や, 肩峰下面に存在する石灰性腱炎を評価 しやすい1,2). 両者の撮影方法について比較すると, 肩

\title{
Examination of the Shoulder Joint Using True Anterior-posterior Photography, Employing a Body Surface Index
}

\author{
Shunsuke Morita, ${ }^{*}$ Hironobu Fujisawa, ${ }^{2}$ Kyoichi Kato, ${ }^{2,3}$ Naoya Nishinaka, ${ }^{4}$ \\ Hiroaki Tsutsui, ${ }^{4,5}$ and Yasuo Nakazawa ${ }^{3,6}$ \\ ${ }^{1}$ Department of Radiology, Showa University Fujigaoka Rehabilitation Hospital \\ ${ }^{2}$ Department of Radiology, Showa University Fujigaoka Hospital \\ ${ }^{3}$ Showa University Graduate School of Nursing and Rehabilitation Sciences \\ ${ }^{4}$ Department of Orthopaedics, Showa University Fujigaoka Hospital \\ ${ }^{5}$ Department of Orthopaedics, Showa University Fujigaoka Rehabilitation Hospital \\ ${ }^{6}$ Department of Radiology, Showa University
}

Received December 16, 2013; Revision accepted April 15, 2014

Code Nos. 111, 112

\section{Summary}

Radiographic examination of the anterior part of the shoulder includes routine anterior-posterior imaging that enables easy visualization of traumatic injuries and true anterior-posterior imaging that enables the visualization of intra-articular injuries. The X-ray incident angle of true anterior-posterior imaging is affected by physique and posture. However, in many reports, the angle is uniformly determined on the basis of the anteroposterior axis and the horizontal plane. We previously reported that the glenohumeral joint can be visualized with good reproducibility by establishing a reference line on the basis of three points on the body as indicators, namely the posterior view of the undersurface of the acromion, the coracoid process, and the inferior angle of the scapula. However, visualizing the undersurface of the acromion using physical indicators to set the angle for imaging remains problematic. In previous reports, the angle was consistently set at $20^{\circ}$ to the horizontal plane, regardless of physique or posture, which resulted in poor reproducibility. After examining the imaging techniques described in previous reports, we describe here an imaging technique using a reference line based on indicators on the surface of the scapula that enables the glenohumeral joint and the undersurface of the acromion to be visualized with good reproducibility.

Key words: shoulder joint, true anterior-posterior, coracoid process, inferior angle, undersurface of the acromion

*Proceeding author 
関節 routine AP 撮影は，前額面に直交するように入射 することで容易に撮影できるのに対し，肩関節 true AP 撮影では，肩甲上腕関節と肩峰下面を描出するため に，体位と X 線入射角を設定する必要がある。これら の角度は，体格や姿勢の違いによって生じる肩甲骨の 傾きに影響されることから，再現性のよい画像を得るこ とが困難である。しかし，過去の報告による撮影法で は，体格や姿勢を考慮せずに体軸と水平面を基準に角 度が定められている1,3〜6)，われわれは，肩甲上腕関節 について，肩甲骨を体表面上から触知することができる 肩峰後角，鳥口突起，肩甲骨下角の 3 点を撮影の基準 点とし，基準点から基準線を設定する(Fig. 1)ことで, 患者の姿勢や体格に影響されない撮影法について報告 した77. しかし，過去の報告に記されている撮影法の根 拠がわからず，姿勢や体格による影響についても不明 であった，特に肩峰下面の描出は，体表指標を用いて 最適角度を設定することが困難であり，再現性よく描出 することができなかっだ8)，今回，われわれは，過去に 報告された肩関節 true AP 撮影法と基準線を用いた肩 関節 true AP 撮影法について検討を行った。また，それ ぞれの撮影法について, 肩峰下面の描出能を評価し, 肩甲骨を体表指標とした肩関節 true AP 撮影の体位お よび肩峰下面を描出するための最適 X 線入射角度を検 討することで，肩甲上腕関節および肩峰下面を同時に 描出できる撮影法を確立したので報告する.

\section{1. 方 法}

\section{1-1 肩関節 true AP 撮影法の臨床上の有用性と意義} 肩関節正面像には routine AP 撮影法と true AP 撮影 法が存在する。前者は，撮影者による技術格差がなく， 再現性よく撮影することができ，直交する scapula-Y 撮 影像を立体的に組み合わせることで，骨折のような外 傷性疾患の描出に適している。一方後者は，撮影者の 技術や経験によって描出能が異なるが1 6,8,9), 肩峰下 面と肩甲上腕関節を描出することによって，非外傷性疾 患の評価に適している. 非外傷性疾患の代表として, 日常診療でも多く遭遇するのが腱板損傷である。腱板 損傷は，加齢的な変化に伴う変性断裂と外傷に伴う外 傷性断裂に分けられるが，変性断裂において，腱板が 機能しないため，三角筋の上方剪断力が優位に働き， 上腕骨頭の上方化を生じる。このような場合，腱板が 肩峰に衝突することで，肩峰下面に刺激を生じ，肩峰 下インピンジメントなどの病態となる。しかし，軟部組 織である腱板は，単純 $\mathrm{X}$ 線撮影上で描出されないた め, 単純 X 線撮影で腱板損傷を評価するには, 肩峰に 生じる骨棘(Fig. 2)や肩峰骨頭間距離(acromiohumeral

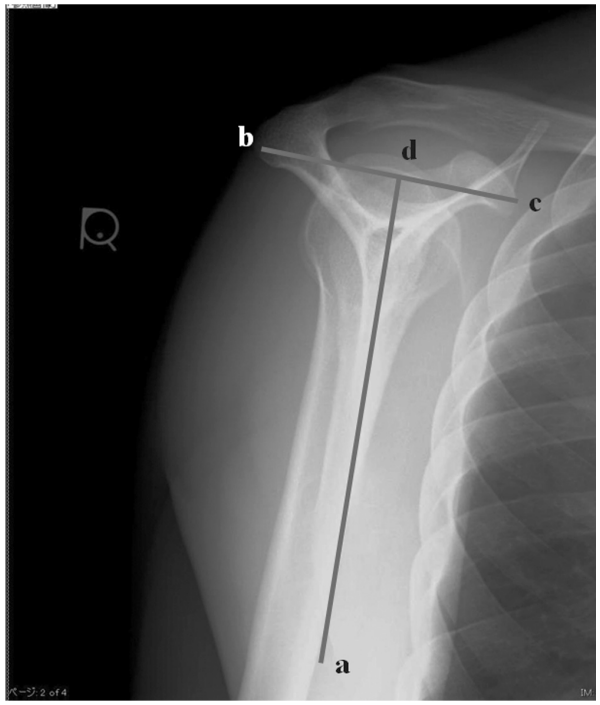

Fig. 1 Reference points and baselines. a: Inferior angle of the scapula b: Acromion c: Coracoid process $\mathrm{d}$ : Mid-point between $\mathrm{b}$ and $\mathrm{c}$ Line a-d: The first base line Line $\mathrm{b}-\mathrm{c}$ : The second base line

interval: AHI)の狭小化のような, 二次的な要因から 腱板損傷を診断することが，臨床上非常に重要であ $ろ^{3,10)}$ ．このため，上腕骨頭と肩峰の関係性を評価する には，単純 X 線撮影正面像が必要となる。特に，AHI の測定には，肩峰と肩峰下面が重なり観察しにくい routine AP 撮影法より, 肩峰下面を接線方向に, 最も 広く描出できる true AP 撮影法が優れている。また,

Fig. 2 で示したように，肩峰に生じた骨棘が原因となる 腱板損傷の評価においても, routine AP 撮影法より, true AP 撮影法が適している3,8,9)，その他にも，大結節 の不正像，囊腫の形成，関節窩の変形，脱臼の有無の 描出には, routine AP 撮影法より true AP 撮影法が適し ている $3^{3,8,9)}$.

\section{1-2過去に報告された撮影法による肩甲上腕関節 描出角度の検討}

両腕を下垂位で撮影した，肩甲骨に骨折や変形のな い100 名の胸部 computed tomography 画像を無作為に 抽出した。この画像を用いて，肩甲骨関節窩の内側縁と 外側縁を結んだ線の垂線と前額面のなす角度 A(Fig. 3) を計測した，また，過去の論文で，われわれが求めた 肩甲棘とカセッテのなす角度 ${ }^{7}$ (平均 11.3 度, 標準偏差 0.78）との有意差について求め, 肩甲上腕関節を広く描 出する基準について検討した.

また，本研究に用いた臨床画像の使用については, 当院倫理委員会の使用許可を得ている. 




Fig. 2 Difference in accuracy using our method.

(a) Shoulder joint using routine AP

(b) Shoulder joint using true AP

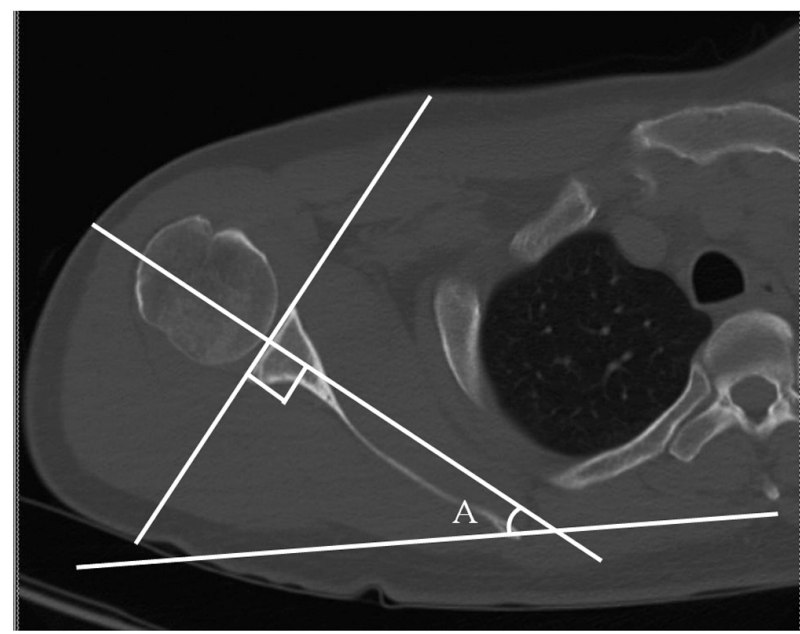

Fig. 3 A: Angle between the coronary line and the shoulder glenoid.
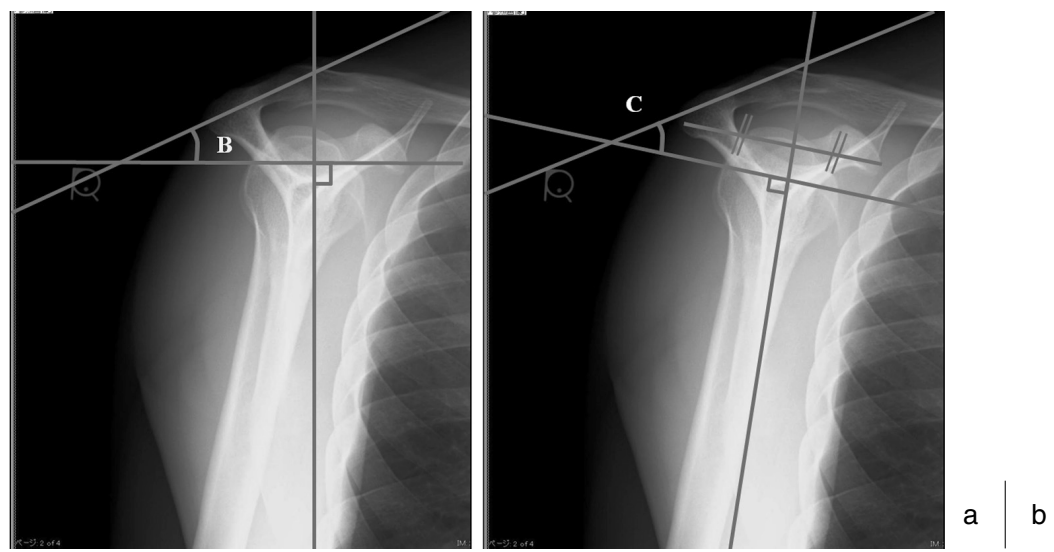

Fig. 4 (a) B: Angle between incident ray and body axis

(b) $\mathrm{C}$ : Angle between incident ray and the first baseline

\section{1-3＼cjkstart過去に報告された撮影法による肩峰下面描出} 角度の検討

無作為に抽出した 100 名の scapula-Y 画像を用い て, 肩峰の前角と後角が重なり, 肩峰下面が最も広く描 出されるX 線入射角を鎖骨, 肩峰の前角, 後角の 3 点 を結ぶ線 (入射線) と水平面とのなす角度 B (Fig. 4a) とし



\section{1-4 第一基準線を用いた肩峰下面描出の検討}

患者の姿勢や体格に影響されない撮影基準として, 肩甲骨の肩峰後角と, 烏口突起を結ぶ中点と肩甲骨下 角を結ぶ線を第一基準線(Fig. 1) とした。次に, 無作為 に抽出した 100 名の scapula-Y 画像を用いて, 肩峰下面 を描出する入射角度を，第一基準線に対する垂線と入 射線のなす角度 $\mathrm{C}(\mathrm{Fig} .4 \mathrm{~b})$ としたとき, $\mathrm{X}$ 線入射角度 $\mathrm{C}$
について計測した。また， X 線入射角度 B と X 線入射 角度 $\mathrm{C}$ との有意差を求め, 基準線が患者の姿勢や体格 に影響されることなく，肩峰下面の描出に有用であるか を検討した。

\section{1-5 第一基準線と第二基準線の関係}

肩峰後角と烏口突起を結ぶ線を第二基準線としたと き，無作為に抽出した 100 名の scapula-Y 画像を用い て，第一基準線と第二基準線のなす角度 $\mathrm{D}$ (Fig. 5) を測 定し，得られた結果から撮影体位を検討した。

\section{1-6 肩関節 true AP 撮影における入射点の検討}

方法 1-3，1-4で用いた入射線の中心点 $\mathrm{E}$ と実際の撮 影で用いる中心点 $\mathrm{F}$ との距離(Fig. 6) から生じる立体角 を計測し，その補正方法を検討した。 


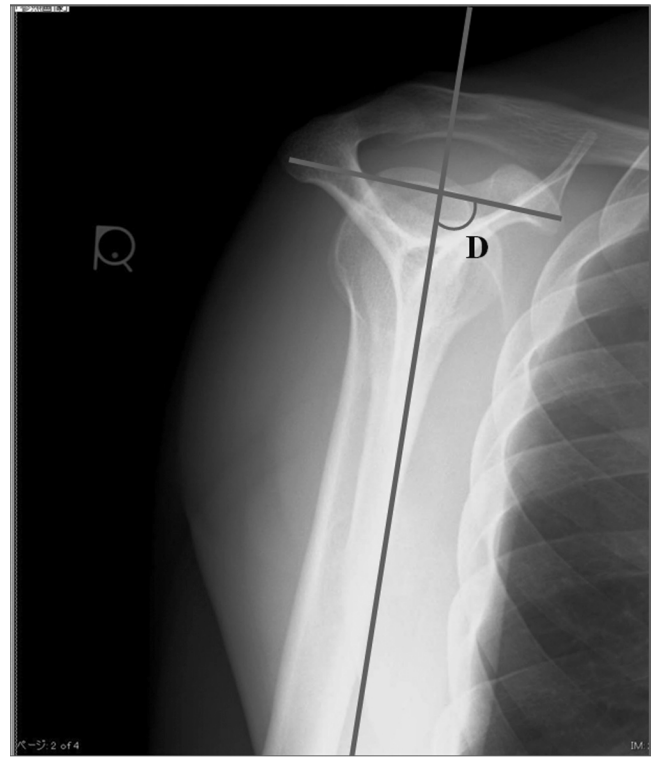

Fig. 5 D: Angle between the first baseline and body axis.

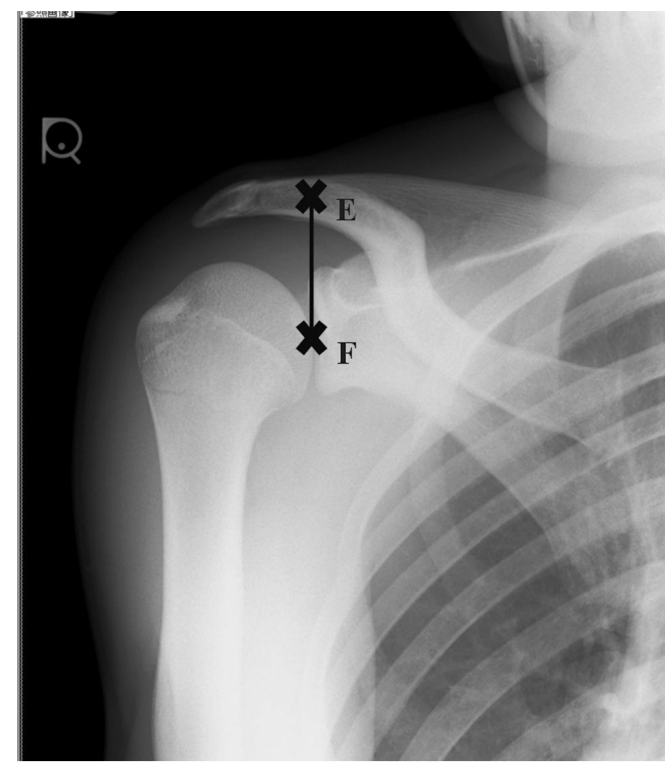

Fig. 6 Examination of incident point.

E: Incident point when we use angle B and angle $\mathrm{C}$

F: Conventional incident point

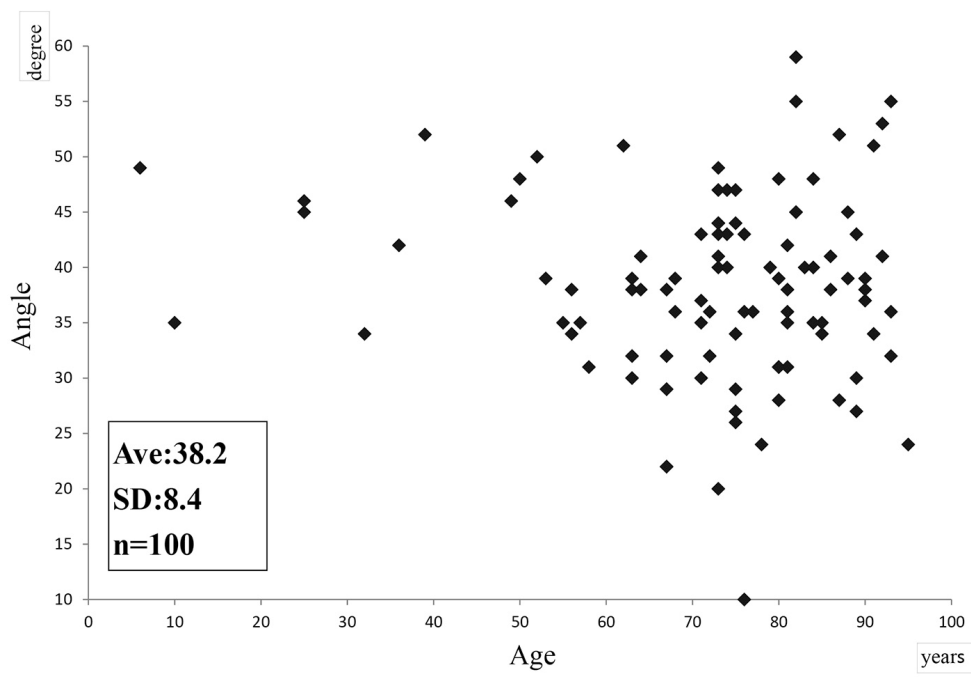

Fig. 7 Relation between age and angle A.

\section{2. 結 果}

\section{2-1 基準の違いによる肩甲上腕関節描出の検討}

前額面を基準とした肩甲上腕関節の描出角度 $\mathrm{A}$ は, 平均 38.2 度, 標準偏差は 8.4 であった(Fig. 7). 角度 A と肩甲棘を基準とした描出角度7) (平均 11.3 度，標準偏 差 0.78)の間には, Mann-Whitneyの U 検定で有意差 $(\mathrm{P}<0.05)$ が認められた。

\section{2-2 体軸と入射線との関係性の検討}

体軸を基準とした $\mathrm{X}$ 線入射角度 $\mathrm{B}$ は, 平均 37.1 度，標準偏差 6.2(Fig. 8) であり，各年齢間でばらつき が大きく，体軸と入射線の間に，相関関係は認められ
なかった。

\section{2-3 基準線と入射線との関係性の検討}

基準線を用いた $\mathrm{X}$ 線入射角度 $\mathrm{C}$ は，平均 26.0 度， 標準偏差 1.7(Fig. 9)であり，年歯間にばらつきが少な く, 基準線と $\mathrm{X}$ 線入射角度 $\mathrm{C}$ の間に，相関関係が認め られた。また， $\mathrm{X}$ 線入射角度 $\mathrm{B}, \mathrm{C}$ の間には，MannWhitney のU 検定で有意差 $(\mathrm{P}<0.05)$ が認められた。

\section{2-4 各基準線の関係性の検討}

第一基準線と第二基準線のなす角度 $\mathrm{D}$ は, 平均 89.8 度，標準偏差 1.3 であった(Fig. 10). 


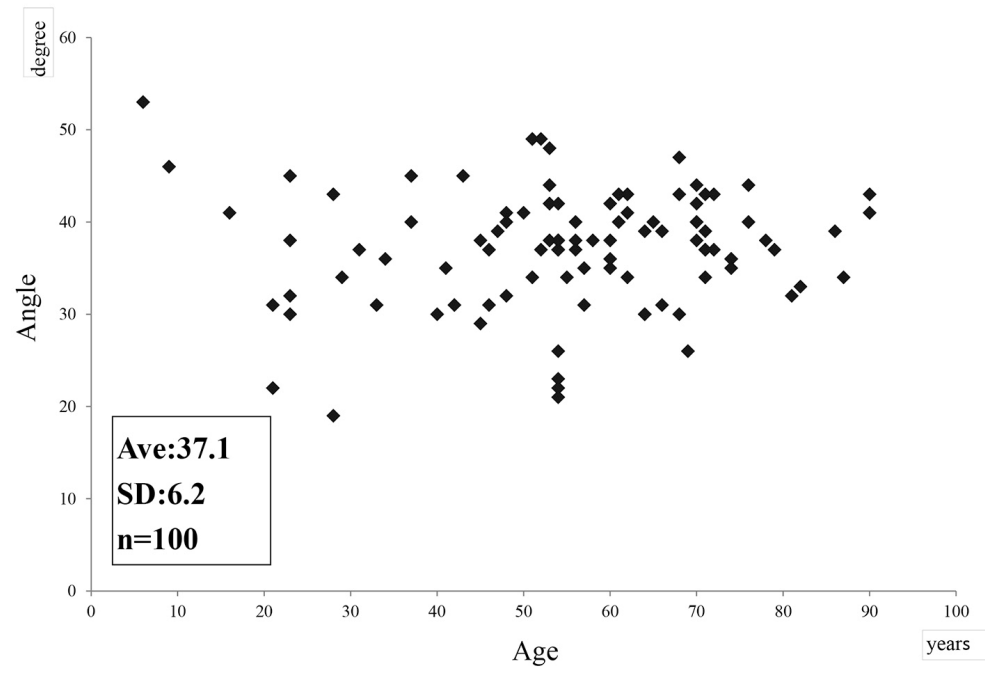

Fig. 8 Relations between age and angle B.



Fig. 9 Relations between age and angle $\mathrm{C}$.

\section{2-5 入射点の検討}

各年齢の入射点 E-F 間の距離は, 平均 $43.5 \mathrm{~mm}$, 標 準偏差 2.2 であった(Fig. 11)。これによって, 生じる立 体角は, source image receptor distance (SIRD) $100 \mathrm{~cm} の$ 場合， 2.5 度となった。

\section{3. 考 察}

\section{3-1 過去に報告された撮影法による肩甲上腕関節 描出角度の検討}

前額面を基準とした肩甲上腕関節の描出角度のばら つきは大きかったここれは前額面と肩甲骨の間に相関関 係がないため, 肩甲骨の傾き3,11１4)によってばらつきが 生じたと考えられた，このばらつきは，患者の姿勢に影 響を受けるため, 自然立位もしくは坐位で行う実際の撮 影では，より大きくなると考えられた。一方で，肩甲棘
を基準にした場合，患者個々のばらつきは少なかった． これは，肩甲棘が肩甲骨上にあるため，肩甲骨の傾きに 左右されず，患者の姿勢に影響されないためであると 考えられた7)。このことから，患者の姿勢や体格に影響 されることなく，肩甲上腕関節を再現性よく描出するた めには，前額面よりも，肩甲骨の体表指標を肩峰後角， 烏口突起，肩甲骨下角にした撮影法が適していると考 えられた

\section{3-2 過去に報告された撮影法による肩峰下面描出} 角度の検討

体軸を基準とした X 線入射角度 $\mathrm{B}$ は，患者ごとのば らつきが大きく，体軸と入射線の間に相関関係は，認め られなかった。この理由として，体軸と肩甲骨の傾きに 相関関係はなく，体軸を基準とした $\mathrm{X}$ 線入射角度 $\mathrm{B}$ 


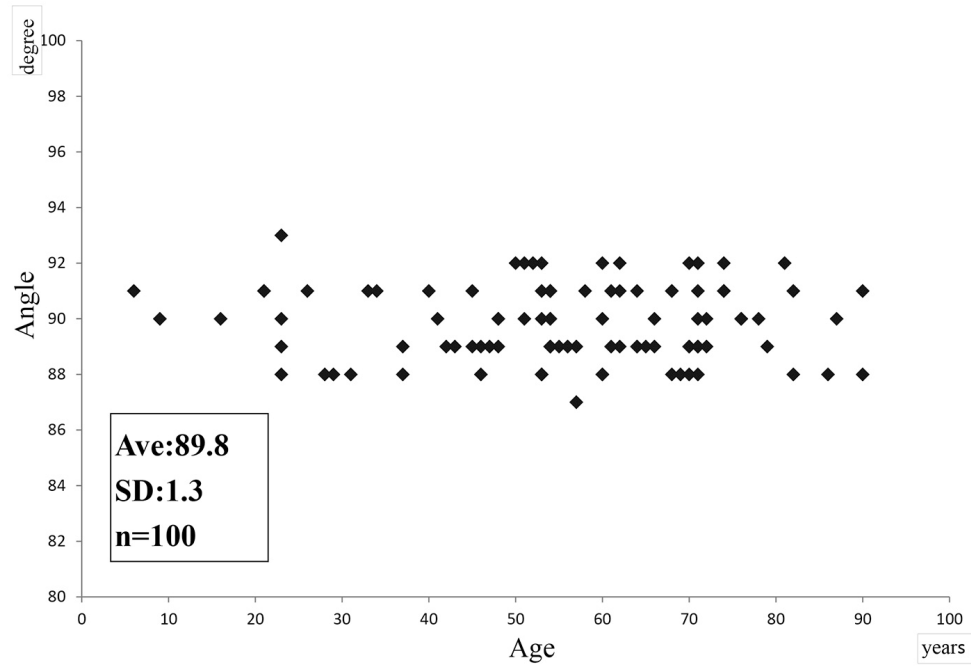

Fig. 10 Relations between age and angle D.

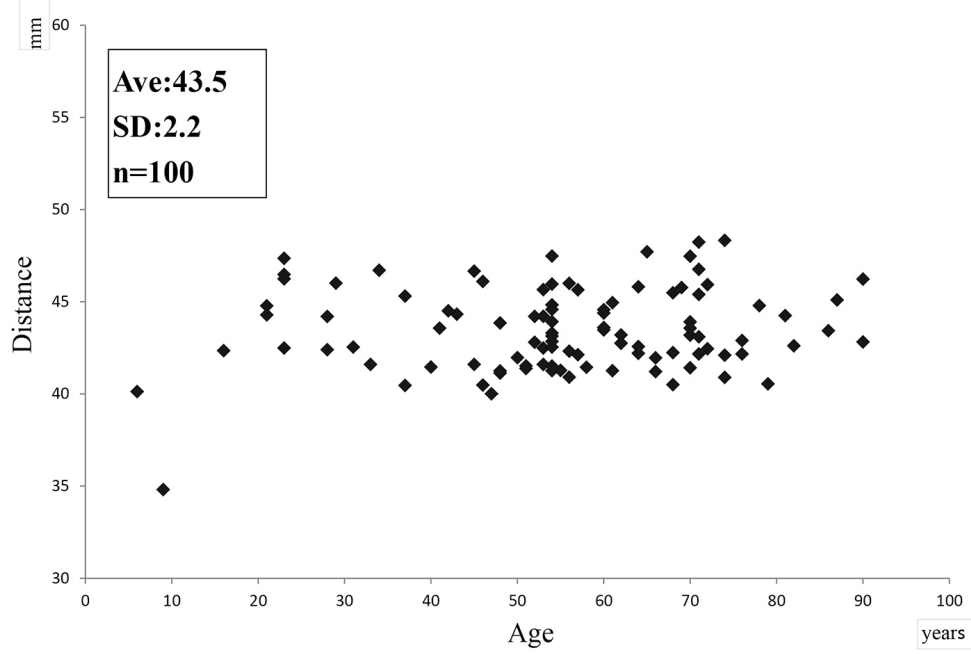

Fig. 11 Relations between age and distance E-F.

は，患者の体型や姿勢によって異なるためであると考え られた。このことから，過去に報告された撮影法1,3〜6 に記されている，水平面に対して，20 度で入射しても 肩峰下面は, 再現性よく描出されないと考えられた。

\section{3-3 基準線を用いた肩峰下面描出角度の検討}

第一基準線を用いた $\mathrm{X}$ 線入射角度 $\mathrm{C}$ は，ばらつきが 少なく，第一基準線と $\mathrm{X}$ 線入射角度 $\mathrm{C}$ の間には相関関 係が認められた。この理由として，第一基準線が肩甲 骨上に存在するため，体型や姿勢の違いによって，肩 甲骨の傾きの影響を受けなかったためと考えられた7). このことから，肩峰下面において，第一基準線は，体表 指標として適していると考えられた，しかし，患者の姿 勢が円背となる場合は，第一基準線が床面に対して垂 直となっていないため, 指標として用いるには不適切で
あった。したがって，第一基準線を用いて撮影を行うた めには，第一基準線を水平面に対して，垂直にする必 要があり，第一基準線と第二基準線のなす角度が，ほ ぼ垂直であることから，第二基準線を水平とすること で，補正できると考えられた。

\section{3-4 肩関節 true AP 撮影における入射点の検討}

入射点を肩甲上腕関節とし SIRDを $100 \mathrm{~cm}$ で撮影し たとき，立体角が 2.5 度生じ，基準線を用いた X 線入 射角度 Cを用いることは不適切であった，立体角に影 響されず撮影を行うには，入射点 $\mathrm{E}$ (Fig. 6)を中心とす ることが適していると考えられた。

\section{4. 結 語}

過去の報告による前額面と水平面を基準とした撮影 

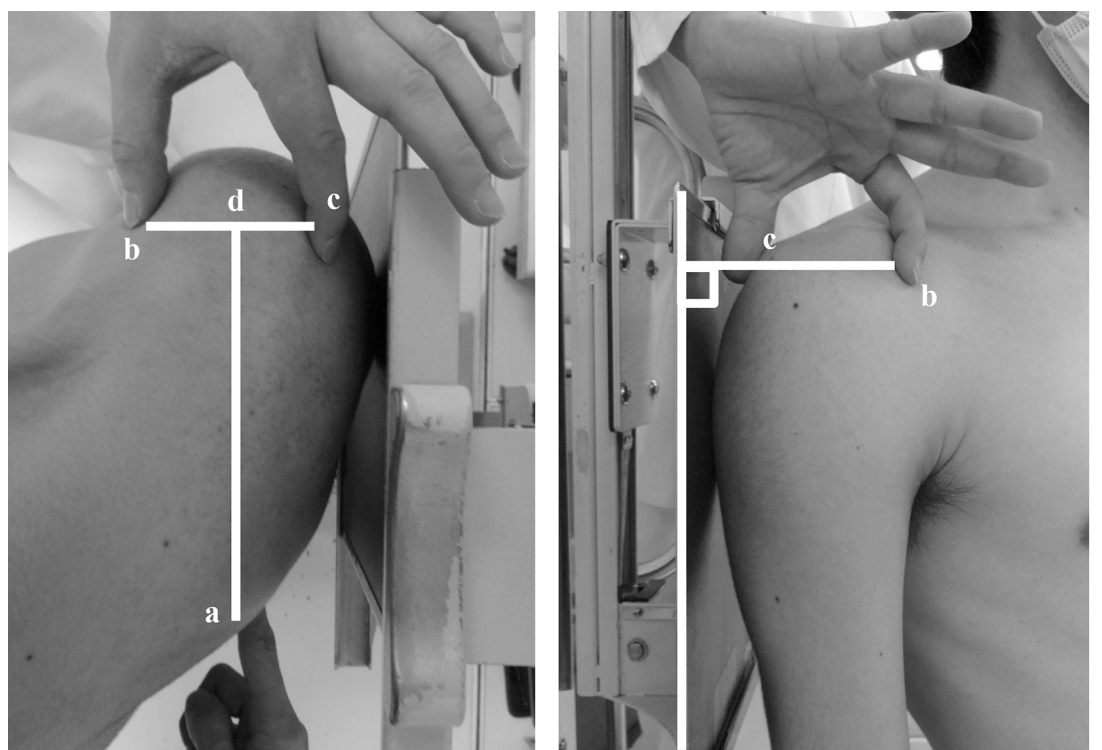

Fig. 12 Photograph of setup.

a: Inferior angle of the scapula

b: Acromion

c: Coracoid process

$\mathrm{d}$ : Mid-point between $\mathrm{b}$ and $\mathrm{c}$

法は，姿勢や体格の違いから生じる肩甲骨の傾きを考 慮していないため，患者個々に対応できず，再現性よく 肩甲上腕関節，肩峰下面を描出することは困難であっ た，われわれは，肩甲骨を体表指標とし，体表面から 触知できる肩峰後角, 烏口突起, 肩甲骨下角から得た 基準線を用いた撮影法が，肩甲骨の傾きに影響を受け ず，肩甲上腕関節，肩峰下面を描出できることを立証し た．第一基準線をカセッテに対して平行，第二基準線 を水平面に平行とし，X線入射角度を頭尾方向より
26.0 度で点 $\mathrm{E}$ (Fig. 6) に入射することで，肩甲上腕関節 と肩峰下面を再現性よく描出することを可能とした (Fig. 12).

\section{謝 辞}

本研究を遂行するにあたり，ご協力いただきました昭 和大学藤が丘病院放射線室ならびに, 昭和大学藤が丘 リハビリテーション病院放射線室の諸兄に深く感謝致し ます。

\section{参考文献}

1）高倉義典, 安藤英次. Chapter 1 肩関節撮影法. 図解 上肢 撮影法. オーム社, 東京, 2011: 1-68.

2) 国分正一, 岩谷 力, 落合直之, 他. 11 肩甲带. 今日の整 形外科治療指針。医学書院，東京，2010: 377-379.

3）信原克哉. 肩一その機能と臨床一. 東京 : 医学書院, 1988.

4) 谷崎 洋, 大棒秀一, 辺見 弘, 他. 胸郭肩関節 2 方向, チェックポイント X 線撮影と画像評価. 医療科学社, 東 京, 2007: 218-219.

5) 鍵田政雄. 5-2 肩関節 (I). 図説単純 X 線撮影法. 金原出 版，東京，2008: 60-61，151。

6) 堀尾重治. 6 肩関節。骨・関節 X 線写真の撮りかたと見か た。医学書院，東京，2007: 60-62.

7）藤澤宏信, 加藤京一, 西村裕樹, 他. Scapula-45 撮影法に おける肩甲上腕関節描出体位の検討。日放技学誌 2012; 68(4): 397-403.

8) 戸山芳昭, 大谷俊郎, 池上博泰, 他. 第二章 肩甲帯. 整 形外科専門医になるための診療スタンダード。羊土社，東
京, 2011: 12-22, 90-140.

9) 難波一能. 肩関節の機能解剖と疾患別至適撮影法. 平成 23 年度 第 2 回放射線セミナー, 浜松, 2011-11, 静岡県放射線 技師会，静岡県放射線技師西部地区会広報誌 2012; 63: 6-9.

10）井上宜充，岡本賢太郎，久合田浩幸，他．肩関節周囲炎後 例における肩峰骨頭間距離と肩関節可動域制限の関連につ いての検討. 理学療法学 2010; 37(3): 174-177.

11）田中雅美，千葉 弘，田崎洋一郎，他．第 2 肩関節撮影法 の検討. 日放技学誌 1996; 52(10): 1398.

12) Fronek J, Warren RF, Bowen M. Posterior subluxation of the glenohumeral joint. J Bone Joint Surg Am 1989; 71(2): 205-216.

13) Poppen NK, Walker PS. Forces at the glenohumeral joint in abduction. Clin Orthop Relat Res 1978; (135): 165-170.

14) Inman VT. Observations on the function of the shoulder joint. J Bone Joint Surg 1994; 26(1): 1-30. 